\title{
Luminol in the forensic science
}

\author{
Luminol na ciência forense
}

\author{
Rafaela Rogiski da Silva ${ }^{1}$, Bruna Carla Agustini ${ }^{2}$, André Luís Lopes da Silva ${ }^{3}$, Henrique \\ Ravanhol Frigeri ${ }^{*}$
}

${ }^{1}$ Graduate Degree in Chemistry; Polytechnic School; Pontifical Catholic University of Parana; 80215-901; Curitiba - PR - Brazil, ${ }^{2}$ Laboratory of Enzymology and Fermentation Technology; 80210-170; Curitiba - PR Brazil, ${ }^{3}$ Health and Biosciences School; Pontifical Catholic University of Parana; 80215-901; Curitiba - PR Brazil.

\begin{abstract}
In a crime scene, the collection of evidence and a subsequent laboratory analysis compose the fundamental steps to allow the expert to reveal the truth for the final verdict in a jury and to bring back the comfort to the victim's family. Bloodstains are usually found and sent to laboratories as a vestige to unravel the origin of the material. However, some scenes are modified in order to conceal the real culprit for the criminal act. For these cases, the luminol reagent can be useful. This test is very often used to visualize occult blood. Luminol is considered the most sensitive test once it can identify the blood presence in scale of nanograms. When this reagent comes into contact with blood, the light emission occurs through a phenomenon known as chemiluminescence. This luminescence can be produced by other interfering compounds, leading to a misinterpretation for the presence of blood. Despite this shortcoming, the present review article highlights the indispensability of the reagent luminol on a crime scene.
\end{abstract}

Key words: luminol, chemiluminescence, crime scene, occult blood, criminalistics, blood stain

\section{INTRODUCTION}

The place where a crime has taken place should be well preserved and investigated in order to provide a reliable report from laboratory analysis and support the defendant judgment. Criminalistics, through a junction of sciences, analyzes the material collected by specialists in the crime scene to identify the source of the evidence. It does not have the role of judge but to seek the truth without deleting the particularity of justice, serving as expert aid in elucidating a crime.

\section{THE BLOOD}

Blood is responsible for gas exchange, transport of hormones and nutrients, pathogenic defense, coagulation, homeostasis and regulation of osmotic pressure. In appearance can be described as a red liquid with an alkaline character that can be divided into two parts: (i) hematocrit (elements or figurative bodies, such as leukocytes, erythrocytes and platelets) and (ii) the liquid portion, composed of approximately $90 \%$ water, referred to as the plasma (Dorea, 1995)

\section{Erythrocytes}

Erythrocytes (Red Blood Cells, RBC) are anucleate cells originated from bone marrow and are constituted mainly by a protein called hemoglobin $(\mathrm{Hb})$ (Gartner \& Hiatt, 2007; Baynes $\&$ Dominiczak, 2007). The main function of this cell is to transport gas. When erythrocytes are situated in the alveoli, this phenomenon is called hematosis in which the exchange of $\mathrm{CO}_{2}$ and $\mathrm{O}_{2}$ is verified. $\mathrm{CO}_{2}$ molecule binds to the heme group of the hemoglobin and is transported to the cells throughout the body in order to generate energy for maintenance of life in a process known as cellular respiration. The $\mathrm{Hb}$ molecule have a tetrahedral structure formed by four polypeptide chains, two alpha and two beta, constituted with heme group - and its structure was proposed in 1959 by Max Perutz and collaborators. The heme

Author for correspondence: henrique.frigeri@gmail.com 
group is formed by the union of the porphyrin IX ring which has four nitrogen atoms with free ligands which bind with the ion $\mathrm{Fe}^{2+}$ to the center by simple covalent and coordinate bounds<smiles></smiles>

A
(Moreira et al.; 2011; Henry, 1999; Baynes \& Dominiczak, 2007). The Figure 1 shows the chemical structure of Protoporphyrin IX and the heme group.<smiles></smiles>

B

Figure 1. Chemical structure of protoporphyrin IX and heme group. This illustration shows two chemical structures: (A) It represents Protoporphyrin IX molecule and (B) ferro-protoporphyrin IX, also called as heme group. Nitrogen atoms form simple covalent (in black) and covalent coordinate bonds (in blue) with $\mathrm{Fe}^{2+}$ ions (in red) in the (B) structure.

\section{Leukocytes}

Leukocytes (White Blood Cells, WBC) are responsible for the body's defense and they are classified in two general groups: i) granulocytes and ii) agranulocytes. The first group has specific cytoplasmic granules and is classified as neutrophils, eosinophils and basophils. The second group has specific granules and is divided into lymphocytes and monocytes (Gartner \& Hiatt, 2007). Among several complex mechanisms of defense, diapedesis is a very common one. In this process, monocytes from blood cross through the cells junctions and transform themselves in phagocytes when they find a foreign or pathogenic agent (Dorea, 1995; Baynes \& Dominiczak, 2007).

\section{Platelets}

Platelets are constituted of megakaryocytes fragments and do not present a nucleus as part of their constitution. These cells participate in blood coagulation by preventing a hemorrhagic process. When a vascular event occurs, the platelets are activated and the mechanism of coagulation starts. In the end of this process, fribrinogen (factor I) is converted to fibrin (factor Ia) which contributes for the clot formation on the injury site (Dorea, 1995; Baynes \&; Dominiczak, 2007).

\section{BLOOD AS CRIME EVIDENCE}

The collection of material from a crime scene from the recovery technique to its storage should be performed very carefully, following a standard protocol. The procedure must be error-free to assure all legal requirements. Another important fact of a criminalistics study is the reconstruction of the event, because, this way is possible to have a greater veracity linking the evidence to the crime.

Evidence can be originated from Biological and Non Biological Source (BS, NBS). Impressions, or fingerprints, with waxes and rust are examples of NBS. Bloodstains, saliva and semen constitute examples of BS. For criminalistics, the interesting in a spot of blood is its nature and its form. It can be identified through reagents that act on hemoglobin and its derivatives (proteins and amino acids). Due to its immutable and nontransferable characteristics these components are capable of identifying the origin of evidence. 
The crime scene can be changed by the defendant to hide any evidence left behind, puzzling the investigation. Advances in forensic science had provided some reagents to support specialists' analysis. These reagents can unravel traces invisible to naked eye. The reagents used by the experts are part of the identification tests. One example is the benzidine test, which identifies the presence of hemoglobin in the sample by the appearance of a blue color. This result demonstrates the oxidation of the hemoglobin molecule by hydrogen peroxide present in the reaction medium. A disadvantage of this method is the DNA degradation within forty-eight hours later use (Tobe et al., 2007). Another test, known as Kastle-Meyer, also reveals a change in medium color in the presence of hemoglobin. It goes from colorless to pink due to the presence of phenolphthalein. Luminol test is a third assay and has been considered one of the most well-known test in the field of forensic science. Luminol reacts with blood promoting light emission.

The luminol test is based on a chemiluminescence reaction (emission of light through a chemical reaction) due to the breakage of a bond containing energy stored. The intensity of the emitted light varies with $\mathrm{pH}$, temperature and concentration of reagents involved. The light emission can cease if there is a critical change in these parameters (Barni et al., 2007).

Among the conditions required for a chemiluminescent reaction to occur, stand out: (i) the reaction must be spontaneous (exothermic process), due to the breakage of the bound; (ii) the direction of the reaction should be favorable to the formation of the excited electronic state and (iii), after the light emission, the excited state is deactivated, causing the electrons back to their ground energy state (Kai et al., 2001).

\section{LUMINOL}

Luminol (5-amino-2,3-dihydro-1,4-phthalazine dione), shown in Figure 2, was first synthesized in 1908 (Barni et al., 2007). Its use as an adjuvant at a crime scene has been reported only in 1937, after experiments with hydrogen peroxide and derivatives from the heme group. Advances on researches with luminol have pointed out inhibitors and interferences that might promote the variation of light emitted by this reagent (Barni et al., 2007).<smiles>Nc1cccc2c(=O)[nH][nH]c(=O)c12</smiles>

A

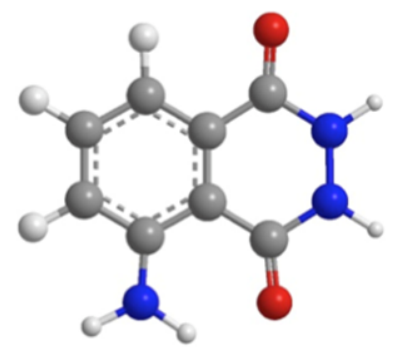

B

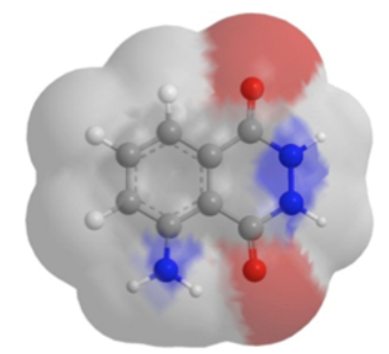

C

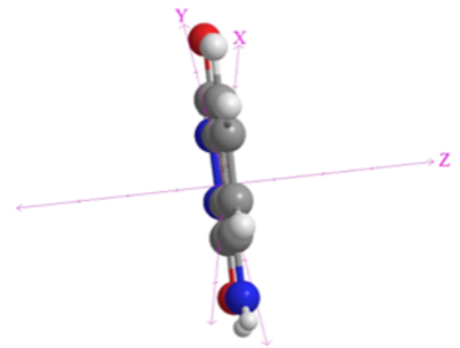

D

Figure 2. Chemical Structure of the Luminol. This illustration shows four representations of luminol structure. (A) It represents a simple structure. (B) It shows the structure in balls and sticks. The atoms are showed by different colors (grey/carbon, white/hydrogen, blue/nitrogen and red/oxygen). (C) It reports, in blue and red colors, points in the molecule with right polarity and electronegativity and (D) Evidences the planar structure of Luminol.

This compound belongs to acyl hydrazide class and is found in crystal form (Barni et al., 2007). Luminol solution is sensitive to acids and strong bases, oxidizing agents and light. Although being considered the most popular assay, Luminol does not have specificity for human blood as well as the other tests mentioned above (Blum et al., 2006).

\section{Luminol solution}

The medium where the test is carried out is composed of sodium hydroxide $(\mathrm{NaOH})$, soda $\left(\mathrm{Na}_{2} \mathrm{CO}_{3} \mathrm{nH}_{2} \mathrm{O}\right)$, hydrogen peroxide $\left(\mathrm{H}_{2} \mathrm{O}_{2}\right)$ and sodium perborate $\left(\mathrm{NaBO}_{3}\right)$. These components are considered irritating to the eyes and mucous, thus the use of personal protective equipment is essential. Federal departments do not control the sale of this product and only a few studies about its toxicity are available in the literature. 
Considering that $\mathrm{pH}$ values between ten and thirteen enable optimal conditions to luminol reaction, the medium $\mathrm{pH}$ must remain alkaline in order to increase the assay's efficiency. Prior experiments have demonstrated that $\mathrm{pH} 11.5$ is ideal to identify blood spots (Blum et al., 2006). The intensity of the light depends on the nature and concentration of the catalyst used, may present and this effect can be photographed and lasting approximately one minute (Barni et al., 2007; Tobe et al., 2007).

The test requires the application of luminol solution in the blood stain, whether visible or not to the naked eye, to prove the result. When compared to other screening tests, Luminol shows higher sensibility, making feasible the detection in nanogram scale. For this reason, depending on the sample concentration it is the best alternative for the analysis. Another variable to luminol assay lies on the surface area in which the reaction will take place. Surfaces of absorbent material, even after a cleaning process or a long period of time from the crime occurrence, will enable a positive result. Luminol solution presents also the advantage of maintaining the integrity of the genetic material after the analysis.

\section{Mechanism of action}

The light emission is associated with the conversion of 3-aminophthalic to 3aminophthalate (Albertin et al., 1998). The first and second steps of the reaction mechanism of Luminol is represented in figures 3 and 4 , respectively.

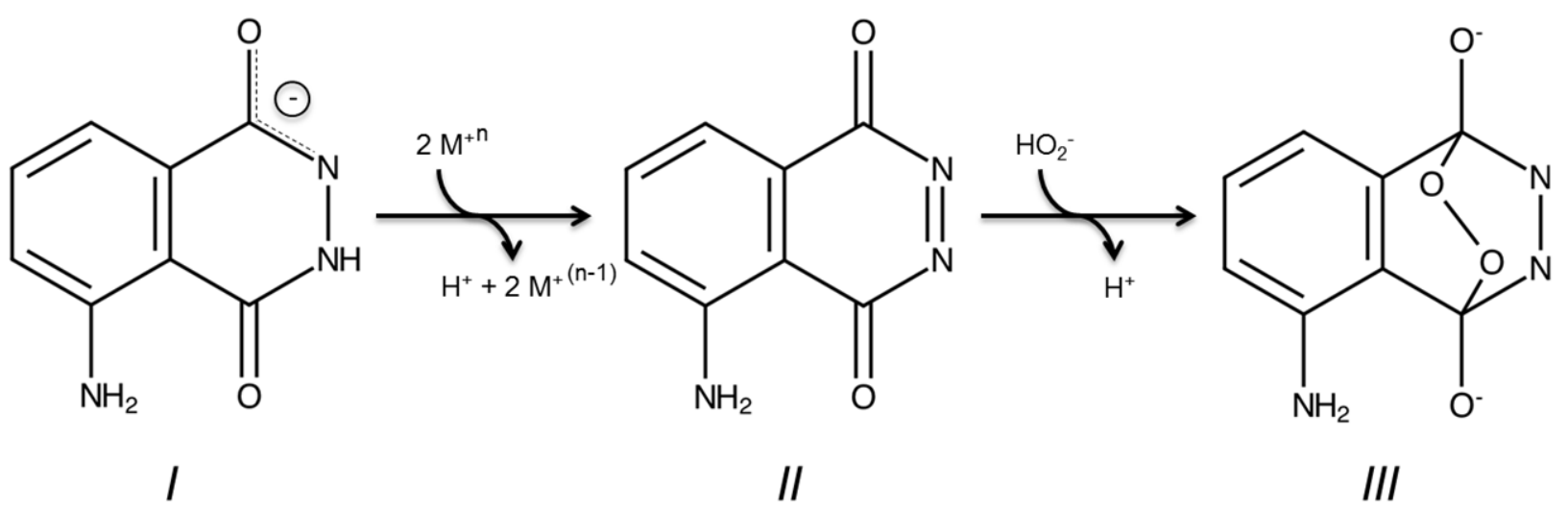

Figure 3. Luminol's mechanism of reaction (Step 1). In solution, hydrogen peroxide oxidizes luminol (I) giving rise to compounds diazoquinone (II) and peroxide ions with the aid of a catalyst that, in the presence of blood, is the cation iron II. Due to its high reactivity, the diazoquinone does not need of catalyst or oxidizing agent and when it reacts with the peroxide ions, there is the formation of the endoperoxide (III). Adapted from Albertin et al. (1998) with modifications.

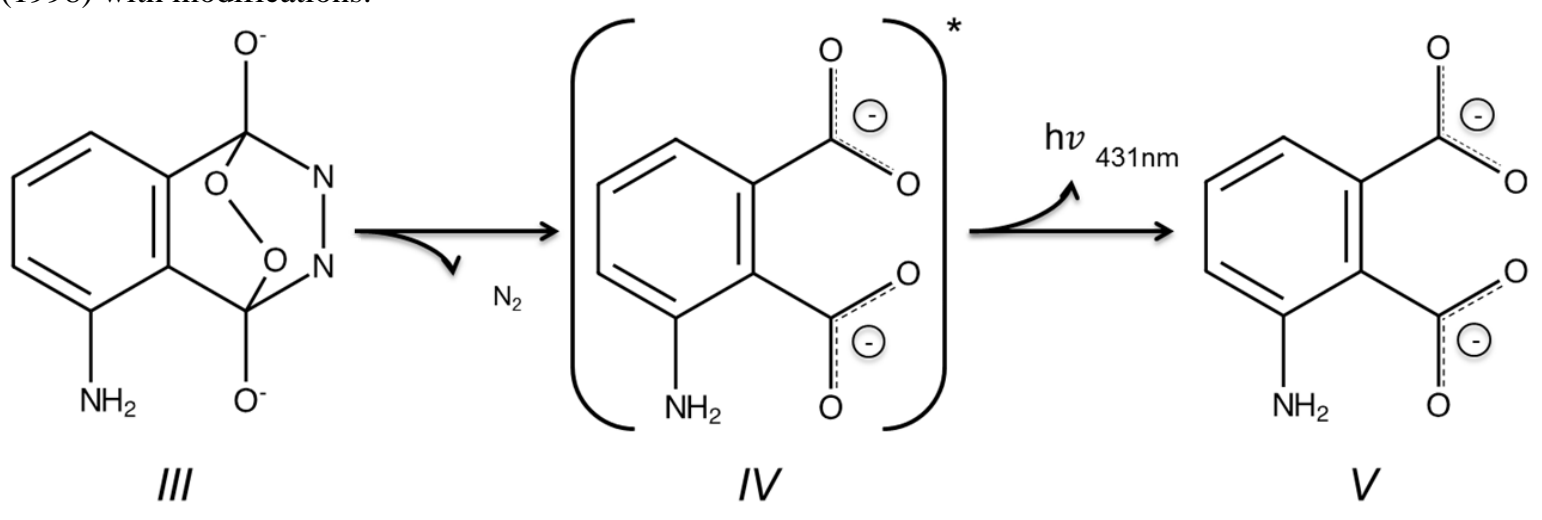

Figure 4. Luminol's mechanism of reaction (Step 2). In this second stage, the endoperoxide (III) after losing molecular nitrogen is in its excited state, characterized by 3 -amino phthalic $(\boldsymbol{I V})$. When it decays, in terms of energy, occurs the release of light that is emitted and is able to measure its intensity and formation of the 3-aminophthalate $(\boldsymbol{V})$. Adapted from Albertin et al. (1998) with modifications. 
With the cleanup of the place as an attempt to disappear with the evidences, interfering compounds can be added to the local modifying the outcome of Luminol's chemiluminescence, concerning to color, intensity and form of distribution. These changes enable the specialists to clearly differentiate a place that has been altered from another that has not.

\section{Interferents}

The result of luminol's assay may be altered by a broad range of interfering compounds, commonly found in home environment, such as iron salts, copper, iodine, potassium permanganate, animal hemoglobin, plant peroxidases and - hypochlorite ion. The latter represents the principal cause of a false positive result.

The clearance of a bloodstain upon washing with hypochlorite solution removes more hemoglobin compared to water alone. As the hemoglobin concentration decreases, the emission of light by Luminol is reduced. However, a successive wash with hypochlorite solution promotes the accumulation of this ion which increases the intensity of light emission by Luminol. In summary, the hemoglobin is replaced by hypochlorite ion leading to a light emission equivalent as the one emitted by a blood stain that has only been washed with water (Creamer et al., 2005; Barni et al., 2007, Castelló et al., 2009).

\section{Beyond the crime scene}

In addition to the role of luminol in revealing hidden blood on a crime scene, it can also be useful in protecting patients and staff inside a hospital. The identification of blood traces on clothes and other hospital utensils helps on disease control, for example, in a hemodialysis unit, preventing any transference of biological material. Luminol's assay has another interesting feature while estimating the age of a bone. This test is capable of identifying traces of hemoglobin after 400 years postmortem (Bergervoet et al., 2008; Ramsthaler et al., 2009; Ramsthaler et al., 2011). The intensity of the light emitted is inversely proportional to the bone's age due to the degradation of hemoglobin as time goes by (Creamer \& Buck, 2009).

\section{CONCLUSION}

The relevance of Luminol for forensic specialists is immeasurable due to its high sensitivity and easy handling. Besides its higher sensitivity, Luminol, as the other used tests, is not specific for human blood. Thus we encourage new researches focusing in the improvement of Luminol's specificity, since there are scarce studies in this area.

\section{ACKNOWLEDGEMENTS}

We would like to thank Pontifical Catholic University of Parana for all support.

\section{RESUMO}

Em uma cena de crime, a coleta de evidencias e a posterior análise laboratorial compõem etapas fundamentais que permitem ao perito revelar a verdade quanto ao veredito final, em um júri, e trazer de volta o conforto para a família de uma vítima de crime. Manchas de sangue são, normalmente, encontradas e enviadas para laboratórios como vestígio para desvendar a origem do material. No entanto, algumas cenas são modificadas a fim de ocultar o verdadeiro culpado pelo ato criminoso. Para estes casos, o reagente luminol pode ser útil. Este teste é muito utilizado para visualizar o sangue oculto. O teste do luminol é considerado o mais sensível, uma vez que pode identificar a presença de sangue na escala de nanogramas. Quando este reagente entra em contato com o sangue, a emissão de luz ocorre através de um fenômeno conhecido como quimioluminescência. Esta luminescência pode ser produzida por outros compostos interferentes, levando a uma má interpretação quanto à presença de sangue. Apesar dos achados recentes, o presente artigo de revisão destaca a indispensabilidade do reagente luminol em uma cena de crime.

Palavras-chave: luminol, quimioluminescência, cena do crime, sangue oculto, criminalística, mancha de sangue

\section{REFERENCES}

ALBERTIN, R.; ARRIBAS, M. A. G.; BASTOS, E. L.; RÖPKE, S.; SAKAI, P. N.; SANCHES, A. M. M.; STEVANI, C. V.; UMEZU, I. S.; YU, J.; BAADER, W. J. Quimiluminescência orgânica: alguns experimentos de demonstração para a sala de aula. Química Nova, v. 21, n. 6, p. 772-779, 1998.

BARNI, F.; LEWIS, S. W.; BERTI, A.; MISKELLY, G. M.; LAGO, G. Forensic application of the luminol reaction as a presumptive test for latent blood detection. Talanta, v. 72, 896-913, 2007. 
BAYNES, J. W.; DOMINICZAK, M. H. Bioquímica Médica, 2 ed. Rio de Janeiro: Elsevier, 2009, 566p.

BERGERVOET, P. W. M.; RIESSEN, N. V.; SEBENS, F. W.; ZWET, W. C. V. D. Application of the forensic Luminol for blood in infection control. Journal of Hospital Infection, v. 68, p. 329-333, 2008 .

BLUM, L. J.; ESPERANÇA, P.; ROCQUEFELTE, $\mathrm{S}$. A new high-performance reagent and procedure for latent bloodstain detection based on luminol chemiluminescence. Canadian Society of Forensic Science, v. 39, n. 3, p. 81-110, 2006.

CASTELLÓ, A.; FRANCÉS, F.; VERDÚ, F. Bleach interference in forensic luminol test on porous surfaces: More about the drying time effect. Talanta, v. 77, p. 1555-1557, 2009.

CREAMER, J. I.; QUICKENDEN, T. I.; CRICHTON, L. B.; ROBERTSON, P.; RUHAYEL, R. Attempted cleaning of bloodstains and its effect on the forensic test. Luminescence, v. 20, p. 411-413, 2005 .

CREAMER, J. I.; BUCK, A. M. The assaying of haemoglobin using luminal chemilumencence and its application to the dating of human skeletal remains, Luminescence, v. 24, p. 311-316, 2009.

DOREA, L. E. As manchas de sangue como indício em local de crime. 2.ed. Porto Alegre: SagraLuzzato, 1995, 96p.

GARTNER, L. P.; HIATT, J. L. Tratado de histologia. Rio de Janeiro (RJ): Guanabara Koogan; 2007.
HENRY, J. B. Diagnósticos clínicos e tratamentos por métodos laboratoriais. 18th edition. Mande: São Paulo, 1999.

KAI, M.; OHTA, K.; KURODA, N.; NAKASHIMA, $\mathrm{K}$. Chemiluminescence and Bioluminescence in DNA Analysis. In: CAMPAÑA, A. M. G.; BAEYENS, W. R. G. Chemiluminescence in analytical chemistry, p. 551-566, 2001.

MOREIRA, L. M.; MORAES, P. C. G.; MENDONÇA, J. P. R. F.; GUIMARÃES, L.; LYO, J. P.; AIMBIR, F.; POLI, A. L.; IMASAT, H. Hemoglobina extracelular gigante de glossoscolex paulistus: um extraordinário sistema supramolecular hemoproteico, Química Nova, v. 34, p. 119-130, 2011 .

RAMSTHALER， F.; KREUTZ, K.; ZIPP, K.; VERHOFF, M. A. Dating skeletal remains with luminol-chemiluminescence. Validity, intra-andinterobserver error, Forensic Science International, v. 187, p. 47-50, 2009.

RAMSTHALER, F.; EBACH, S. C.; BIRNGRUBER, C. G.; VERHOFF, M. A. Postmortem interval of skeletal remain through the detection of intraosseal hemin traces. A comparison of UV-fluorescence luminol, Hexagon-OBTI, and Combur test, Forensic Science International, v. 36, p. $153-160,2011$.

TOBE, S. S.; WATSON, N. L.; DAIÊD, N. N. Evaluation of six presuntive tests for blood, their specificity, sensitivity and effect on high molecularweight DNA. Journal Forensic Science, v. 52, p. 102-109, 2007. 